\title{
Analysis Socioeconomic Status of Farmers Adopted Agroforestry of Basavanapura and Hejjige Village, Nanjangud, India
}

\author{
Satyameshwari Chouhan $^{1 *}$, Sameer Daniel ${ }^{1}$, Arun Alfred David ${ }^{2}$ and Anupriya Paul ${ }^{3}$ \\ ${ }^{1}$ Department of Silviculture and Agroforestry, College of Forestry, ${ }^{2}$ Department of Soil Science \\ and Agricultural Chemistry, NIA, ${ }^{3}$ Department of Mathematics and Statistics, Sam \\ Higginbottom University of Agriculture Technology and Sciences, Allahabad, U.P., India \\ *Corresponding author
}

\begin{tabular}{|c|c|}
\hline & $\mathbf{B} \mathbf{S} \mathbf{T} A \mathbf{C} \mathbf{T}$ \\
\hline & \multirow{8}{*}{$\begin{array}{l}\text { Socioeconomic survey performed on the selected farmers whose primary source of income } \\
\text { is agriculture and adopting agroforestry in their farm land. Survey is done to analyze the } \\
\text { social and economic status of the selected farmers. Most of the farmers are less educated } \\
\text { but still they are accepting the new changes in agroforestry pattern, keeping small and } \\
\text { medium sized nuclear family to meet economic needs and maintaining social status. As the } \\
\text { farmers of Basavanapura and Hejjige village are educated till primary school but still due } \\
\text { to indigenous knowledge of tree cultivation in farm land promoting them to cultivate } \\
\text { horticulture crop like Arecanut, coconut, Sapota and banana with agriculture crops or } \\
\text { pasture crops for commercial purpose and forest tree species are grown only on bunds or in } \\
\text { scattered manner whereas large scale farmers grown Teak (Tectona grandis L.) and Silver } \\
\text { oak (Grevillea robusta L.) plantations in their farm lands to increase the efficiency of the } \\
\text { use of resources and land-use practices and by introducing agroforestry enterprises in order } \\
\text { to produce sustainable increases in incomes and living standards. Due to changing climate } \\
\text { and rainfall pattern farmers are facing many problems which leads to grow alternative } \\
\text { crops like Sugarcane, tomato, chili, ragi, maize and vegetable crops in their agricultural } \\
\text { land. Altogether leads to social equity by increasing socioeconomic standard. }\end{array}$} \\
\hline Keywords & \\
\hline $\begin{array}{l}\text { Socioeconomic, } \\
\text { A groforestry }\end{array}$ & \\
\hline Horticulture, & \\
\hline Bunds, Pasture. & \\
\hline Article Info & \\
\hline $\begin{array}{l}\text { Accepted: } \\
\text { 19 June } 2017 \\
\text { Available Online: } \\
10 \text { July } 2017\end{array}$ & \\
\hline & \\
\hline
\end{tabular}

\section{Introduction}

Agroforestry being a land use system where not only trees are associated with agricultural crops but is often associated with one or more kind of animal species naturally lend it too many definitions as the term encompass an assortment of varied practices. The Agroforestry farmers allocated more land to agricultural crops relative to forest crops in the ratio 4:1. Various levels of agricultural and forest crop combinations to reduce risk were made. Risk adverse farmers plant more forest crops on their Agroforestry farms. The tolerable minimum risk system is an
Agroforestry system in which 80 per cent of the land is allocated to forest crops and 20 per cent is used for agricultural crops. Mercer (1993) states that agroforestry projects have two main objectives: first, to increase the efficiency of the use of rural resources by reducing or eliminating ecologically destructive land-use practices and by introducing new or improved agroforestry enterprises in order to produce sustainable increases in incomes and living standards, and second, to provide for social equity. Estimating the socio-economic impact of an 
agroforestry project is a way to measure the success of meeting the above fundamental objectives of economic and social equity/distributive efficiency. Uniqueness of agroforestry is likely to influence adoption in a different way and hence the need for further investigation (Kobwe, 2010) who stated a need to establish the minimum required land size for a farmer to be able to engage in agroforestry practices and the percentage of farmers above that threshold. In India, the second largest populated and one of the fastest growing economy in the world, having several socio-economic issues, which cannot cope with the pace of economic growth. There is a commonly saying in India that "India lives in villages" and it is true that approximately $70 \%$ of the population are residing in rural areas and the tremendous growth in economy is does not truly benefits the rural people (Singh, 2010).

Mutonyi and Fungo (2011) did a survey study to determine the level of awareness of the various agroforestry technologies for livelihood improvement and to assess opinions of farmers about the usefulness of agroforestry technologies. The results of their study came out with the factors that significantly affect adoption home garden practices were land size, level of income derived from agroforestry, land tenure, exposure to technology, training in any agroforestry technology and exposure presence demonstration sites in are. However for scattered tree practice, land tenure found to affect adoption significantly. The study also revealed low level of awareness of the various agroforestry technologies; however they also reported high level of willingness to adopt these technologies if introduced. Later in year 2011, Chauhan and Chauhan (2011) presented a detailed account on constraints such as legal, financial, technical, availability of planting stock, awareness/attitude of farmers etc. in adoption of short rotation forestry. In many recent works, the impact of factors such as credit, information availability, risk, on farmer adoption behavior also has been investigated Irshad et al., (2011) who explored and identified socio- economic factors that affect the adoption of agroforestry practices. These include beliefs and farmers' perceptions towards agroforestry, socioeconomic characters of farmers and constraints for development of agroforestry. Focusing on marketing aspects of agroforestry, (Basamba et al., 2012) reported that only a few agroforestry farmers participate in the marketing of their agroforestry products.

Using logit model, he revealed that the socioeconomic factors that affect farmers' participation in agro-forestry market include age, house hold size, education level, farm size, access to credit and number of extension visits. Relating to constraints and farmer's belief, Hussain et al., (2012) explored a study to indentify the belief that underlies farmers' decision to engage in agroforestry in three randomly selected divisional headquarters. In this study, they found out favorable attitudes towards farm forestry system and suggested that planting tree will increase income, and meet household requirements for fuel wood and timber and provide them with a healthy environment to work.

\section{Materials and Methods}

The study villages are Basavanapura and Hejjige (Nanjangud block of Mysore district) has about 157 houses in Basavanapura village and 657 houses in Hejjige village. A random survey of 150 farmers was done for the socioeconomic characterization. The respondent farmers are classified into small, medium and large farmer categorized on the basis of their landholding. Farmer with landholding of 1 to 5 acre was considered as small farmer, farmers with farm size of between 6 ha and 14 
acre were considered as medium farmers and those farmers who had land holdings more than 15 acre were reckoned as large farmers. This classification provides distribution of farmers' according to their land holdings which indirectly indicate the status of the farmers of the region. A structured schedule was developed for the socioeconomic survey. Adopting simple survey method in two villages was selected from Nanjangud block of Mysore district. In each of the selected villages, 150 farmers with some form of agroforestry were selected. Thus, two villages from Nanjangud block formed two sample units each of 150 farmers for the study.

The farmers' data was post stratified to compare across the farm- holding size classes. Since the trees are naturally growing especially in traditional agroforestry region and are just allowed to be thriving by the farmers, the benefits associated with the trees like obtaining firewood, fodder, fruits etc. are considered negligible. Therefore, only the benefits and role of income from trees grown in the farm land are taken into account in order to emphasize socio-economic status of the farmers.

Primary socioeconomic data was gathered through key informant and individual farmer interviews. All farmer practicing agroforestry were interviewed regarding their farms and their perceived benefits (socioeconomic) from agroforestry.

The study was confined to only one site and for only one cropping season due to time and resource constraints. It was pretested before undertaking the socioeconomic survey by administering the schedule to selected farmers whose primary occupation is agriculture in the study villages. The schedule covered various aspects pertaining to general information about the family, land holdings, crops cultivated, livestock and other assets.

\section{Results and Discussion}

\section{Education status}

Through the survey finding, $79.33 \%$ and $78 \%$ farmers are educated till primary school of Basavanapura and Hejjige village respectively. As per observation it has been found that the majority of farmers are educated till primary school. But because of traditional pattern of farming and knowledge farmers were practicing agroforestry. $\mathrm{Z}_{\mathrm{cal}}=$ 0.084 and $Z_{\alpha}=1.96$ ( $\alpha$ at 0.05 or $5 \%$ ); Here, $\mathrm{Z}_{\mathrm{cal}}<\mathrm{Z}_{\alpha}$ so $\mathrm{z}$-Test is not significant and the null hypothesis is accepted $H_{0}: \mu_{1}=$ $\mu_{2}$ Where $H_{0}=$ the null hypothesis, $\mu_{1}=$ the mean of farmers of Basavanapura and $\mu_{2}=$ the mean of Hejjige village (Table 1 and Fig. 1).

\section{Type of family}

The tendency of the family segregation is common in recent years and also the people interested to live independently for their better living standards.

It leads to division of the families into nuclear families. $62 \%$ and $72.67 \%$ farmers having nuclear family and $38 \%$ and $27.33 \%$ farmers having joint family of Basavanapura and Hejjige village respectively. $Z_{\text {cal }}=0$ and $Z_{\alpha}=$ 1.96 ( $\alpha$ at 0.05 or $5 \%$ ). Here, $Z_{\text {cal }}<Z_{\alpha}$ so $Z^{-}$ Test is not significant and the null hypothesis is accepted (Table 2 and Fig. 2).

\section{Size of the family}

With respect to size of the family Hejjige village farmers having $63.33 \%$ small sized family (4 members) whereas Basavanapura village having $52.67 \%$ medium sized (5 - 9 members including grandparents and bachelor siblings). Most of the farmers of Hejjige village having small sized family whereas medium sized family observed in Basavanapura village (Fig. 3). 
Table.1 Education level of farmers of Basavanapura and Hejjige village (Nanjangud Block Mysore Karnataka)

\begin{tabular}{llllll}
\hline $\begin{array}{l}\text { Sr. } \\
\text { No. }\end{array}$ & Category & $\begin{array}{c}\text { No. of respondent of } \\
\text { Basavanapura village }\end{array}$ & $\%$ & $\begin{array}{l}\text { No. of respondent of } \\
\text { Hejjige village }\end{array}$ & $\%$ \\
\hline 1. & Illiterate & 4 & 2.67 & 3 & 2 \\
2. & Primary (1st to 5th class) & 119 & 79.33 & 117 & 78 \\
3. & High school & 16 & 10.67 & 13 & 8.67 \\
4. & Graduate and above & 11 & 7.33 & 4 & 2.67 \\
\hline
\end{tabular}

\begin{tabular}{lcc}
\hline & Basavanapura village & Hejjige village \\
\hline Mean & 37.5 & 34.25 \\
Known Variance & 2976.33 & 3063.58 \\
Observations & 4 & 4 \\
$\mathbf{z}$ & 0.083636938 & \\
$\mathbf{P}(\mathbf{Z}<=\mathbf{z})$ two-tail & 0.933345098 & \\
$\mathbf{z}$ Critical two-tail & 1.959963985 & \\
\hline
\end{tabular}

Table.2 Types of family of farmers of Basavanapura and Hejjige village (Nanjangud Block Mysore Karnataka)

\begin{tabular}{|c|c|c|c|c|c|}
\hline Sr. No & Family type & $\begin{array}{l}\text { No. of respondent of } \\
\text { Basavanapura village }\end{array}$ & \multicolumn{2}{|c|}{ No. of respondent of } & $\%$ \\
\hline 1. & Nuclear & 93 & 62 & 109 & 72.67 \\
\hline \multirow[t]{2}{*}{2.} & Joint & 57 & 38 & 41 & 27.33 \\
\hline & & \multicolumn{2}{|c|}{ Basavanapura village } & Hejjige village & \\
\hline \multicolumn{2}{|c|}{ Mean } & \multicolumn{2}{|l|}{75} & 75 & \\
\hline \multicolumn{2}{|c|}{ Known Variance } & \multicolumn{2}{|l|}{648} & 2312 & \\
\hline \multicolumn{2}{|c|}{ Observations } & \multicolumn{2}{|l|}{2} & 2 & \\
\hline \multicolumn{2}{|l|}{$\mathbf{z}$} & \multicolumn{2}{|l|}{0} & & \\
\hline \multicolumn{2}{|c|}{$P(Z<=z)$ two-tail } & \multicolumn{2}{|l|}{1} & & \\
\hline \multicolumn{2}{|c|}{ z Critical two-tail } & \multicolumn{2}{|c|}{1.959963985} & & \\
\hline
\end{tabular}


Fig.1 Education level of farmers of Basavanapura and Hejjige village (Nanjangud Block Mysore Karnataka)

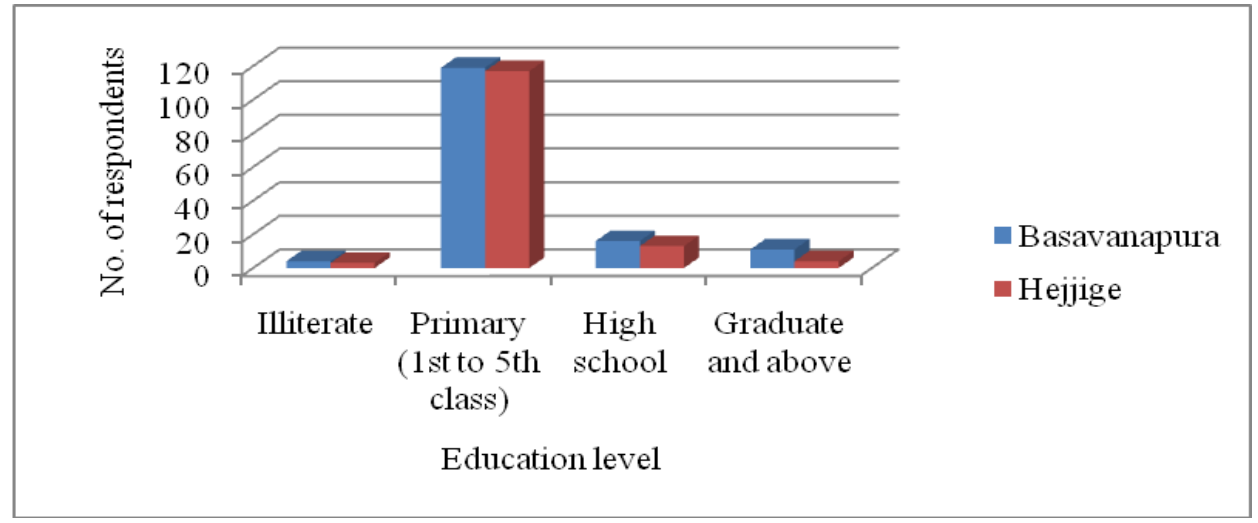

Fig.2 Types of family of farmers of Basavanapura and Hejjige village (Nanjangud Block Mysore Karnataka)

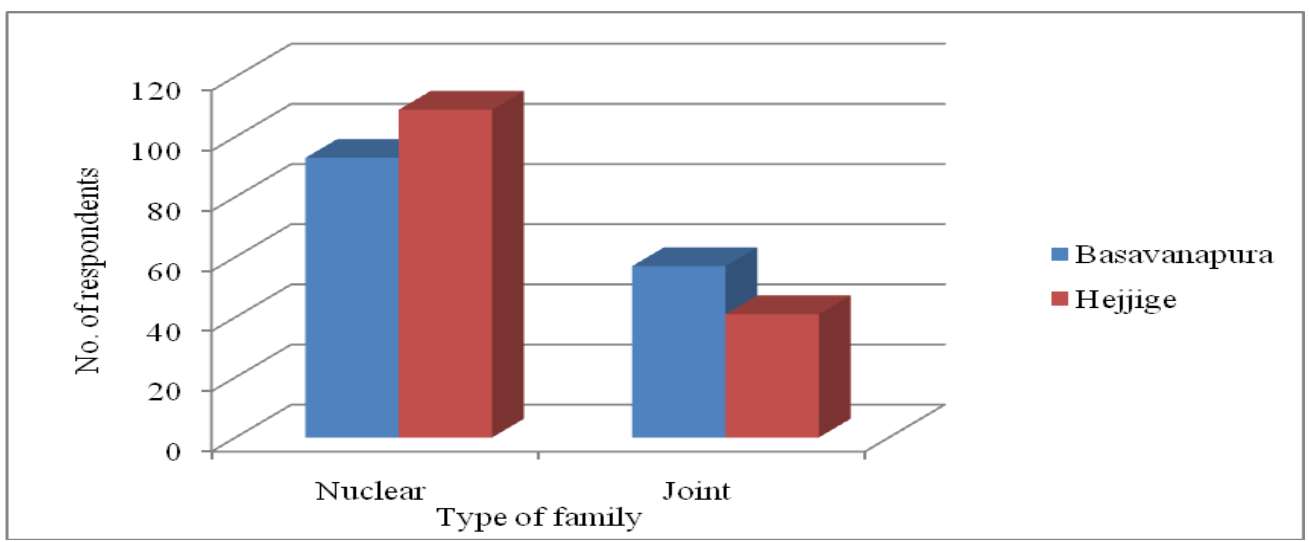

Fig.3 Size of family of farmers of Basavanapura and Hejjige village (Nanjungud block Mysore Karnataka)

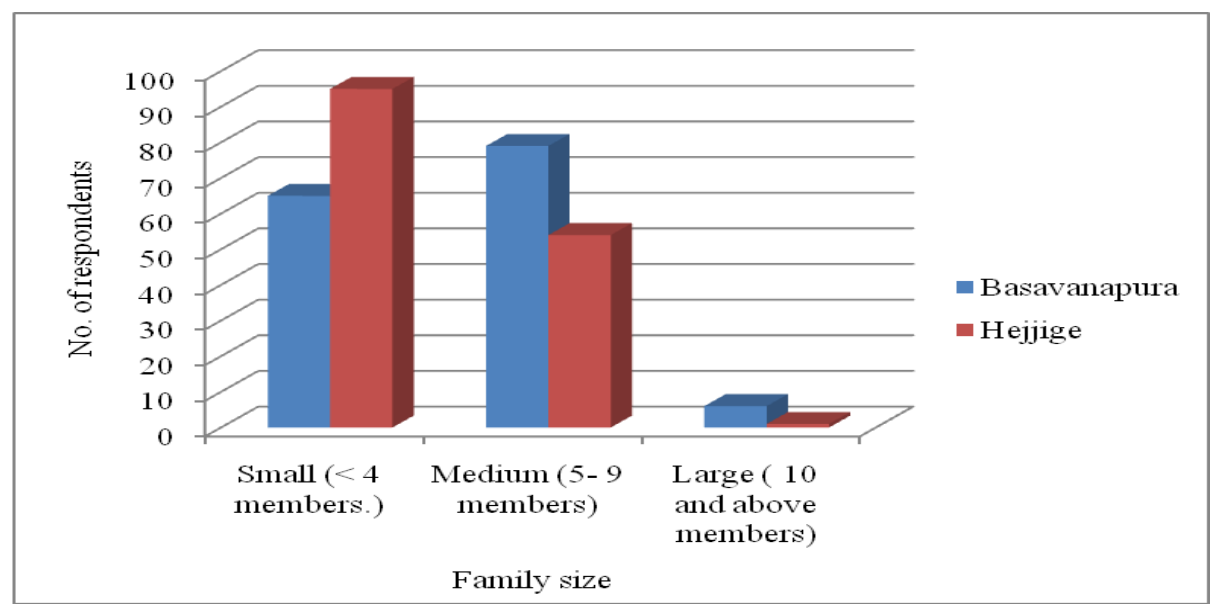


Fig.4 Land Productivity by Farmers of Basavanapura and Hejjige village (Nanjangud block Mysore Karnataka)

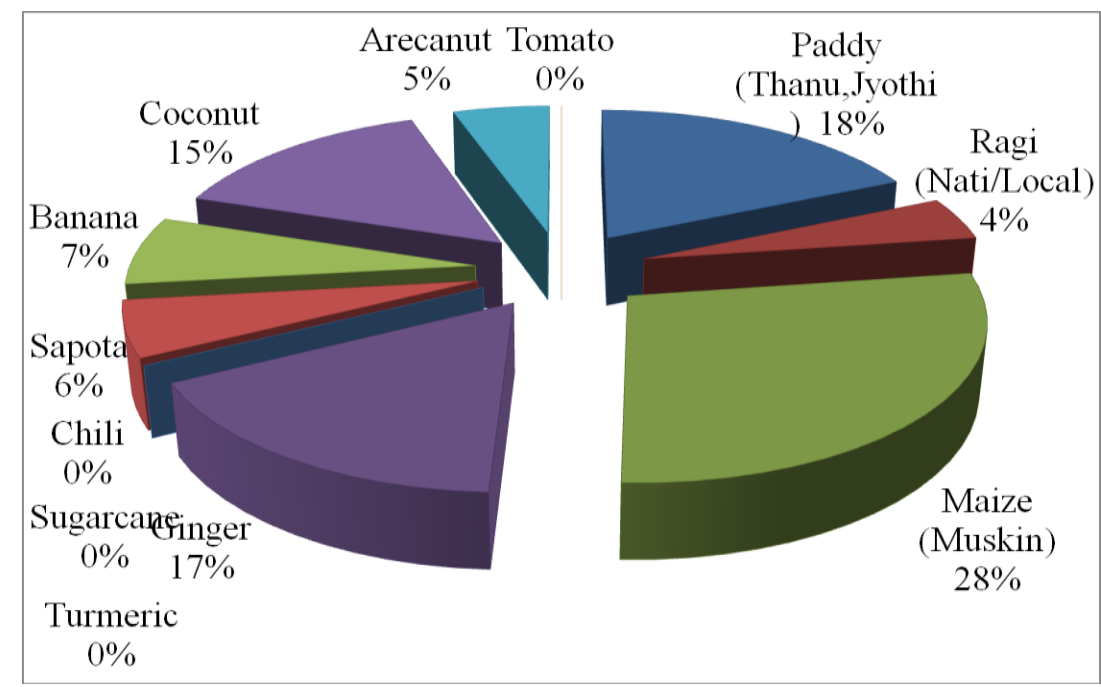

Table.3 Size of Family of Farmers of Basavanapura and Hejjige Village (Nanjungud block Mysore Karnataka)

\begin{tabular}{|c|c|c|c|c|}
\hline Sr. No. & Family size & $\begin{array}{l}\text { No. of respondent of } \\
\text { Basavanapura village }\end{array}$ & $\%$ & $\begin{array}{l}\text { No. of respondent of } \\
\text { Hejjige village }\end{array}$ \\
\hline 1. & Small $(<4$ members $)$ & 65 & 43.33 & 95 \\
\hline 2. & Medium (5- 9 members) & 79 & 52.67 & 54 \\
\hline \multirow[t]{8}{*}{3.} & Large (10 and above members) & 6 & 4.00 & 1 \\
\hline & & Basavanapura villag & & Hejjige village \\
\hline & $\overline{\text { Mean }}$ & 50 & & 50 \\
\hline & Known Variance & 1501 & & 2221 \\
\hline & Observations & 3 & & 3 \\
\hline & $\mathbf{z}$ & 0 & & \\
\hline & $P(Z<=z)$ two-tail & 1 & & \\
\hline & z Critical two-tail & 1.959964 & & \\
\hline
\end{tabular}


Table.4 Land Productivity by Farmers of Basavanapura and Hejjige village (Nanjungud block Mysore Karnataka)

\begin{tabular}{lll}
\hline & Basavanapura village & Hejjige village \\
\hline Mean & 47.875 & 54.625 \\
Known Variance & 1020.98 & 871.7 \\
Observations & 8 & 8 \\
$\mathbf{z}$ & -0.43884 & \\
$\mathbf{P}(\mathbf{Z}<=\mathbf{z})$ two-tail & 0.660775 & \\
$\mathbf{z}$ Critical two-tail & 1.959964 & \\
\hline
\end{tabular}

\begin{tabular}{|c|c|c|c|c|c|c|c|c|c|}
\hline \multirow{2}{*}{$\begin{array}{l}\text { Sr. } \\
\text { No. } \\
1 .\end{array}$} & \multirow{2}{*}{$\begin{array}{l}\text { Crop (variety) } \\
\text { Paddy (Thanu,Jyothi) }\end{array}$} & \multirow{2}{*}{$\begin{array}{l}\text { No. of } \\
\text { respondent of } \\
\text { Basavanapura } \\
\text { village }\end{array}$} & \multirow{2}{*}{$\begin{array}{l}\% \\
46.66\end{array}$} & \multirow{2}{*}{$\begin{array}{l}\text { No. of } \\
\text { respondent of } \\
\text { Hejjige } \\
\text { village } \\
-\end{array}$} & \multirow{2}{*}{$\%$} & \multicolumn{2}{|c|}{ Avg. cost (Rupee) } & \multicolumn{2}{|c|}{ Avg. yield (Quintals) } \\
\hline & & & & & & 1655 & - & 66.07 & 66.07 \\
\hline 2. & Ragi (Nati/Local) & 17 & 11.33 & - & - & 1571 & - & 71.18 & - \\
\hline 3. & Maize (Muskin) & 107 & 71.33 & - & - & 1425 & - & - & - \\
\hline 4. & Ginger & 64 & 42.66 & - & - & - & 3176 & - & 116.89 \\
\hline 5. & Turmeric & - & - & 64 & 42.66 & 3077 & - & 128.36 & - \\
\hline 6. & Chili & - & - & 46 & 30.66 & 1647 & - & 61.17 & - \\
\hline 7. & Sugarcane & - & - & 75 & 50 & 2395 & - & 58.64 & - \\
\hline 8. & Sapota & 22 & 14.66 & 17 & 11.33 & 2127 & 2335 & 13.36 & 23.5 \\
\hline 9. & Banana & 27 & 18 & 34 & 22.66 & 1177 & 1105 & 9.31 & 11.41 \\
\hline 10. & Coconut & 56 & 37.33 & 71 & 47.33 & 1131 & 1134 & 16.48 & 16.84 \\
\hline 11. & Arecanut & 20 & 13.33 & 25 & 16.66 & 6440 & 6576 & 15.96 & 17.95 \\
\hline 12. & Tomato & - & - & 105 & 70 & 1314 & - & 52.26 & - \\
\hline
\end{tabular}


The majority of the families had husband, wife and their children living together as nuclear family the children's were depended on their parents. $Z_{\text {cal }}=0$ and $Z_{\alpha}=1.96(\alpha$ at 0.05 or $5 \%$ ). Here, $Z_{\text {cal }}<Z_{\alpha}$ so $z$-Test is not significant and the null hypothesis is accepted.

\section{Land productivity}

Farmers are cultivating different crops according to climatic conditions and availability of water. Crops cultivated in both the villages are separately taken into account. Paddy, Ragi, Maize (Muskin), Ginger, Sapota, Banana, Coconut and Arecanut is cultivated by the farmers of Basavanapura village whereas turmeric, Chili, sugarcane, Tomato, Sapota, Banana, Coconut and Arecanut (Horticulture component) cultivated by farmers of Hejjige village. $Z_{\mathrm{cal}}=-0.44$ and $\mathrm{Z}_{\alpha}=1.96$ ( $\alpha$ at 0.05 or $5 \%$ ). Here, $\mathrm{Z}_{\mathrm{cal}}<\mathrm{Z}_{\alpha}$ So $z$-Test is not significant and the null hypothesis is accepted.

\section{Acknowledgement}

Author is thankful to Head of the Department of Silviculture and Agroforestry, College of Forestry for the providing necessary facility to carry out this research work.

\section{References}

Alavalapati, J., Nair, P. K. R., Palo, J. And Mery, G. 2001. Socioeconomic and institutional perspectives of agroforestry. World forests, markets and policies: $71-81$.

Chauhan, S. K. and Chauhan, R. 2011. Short rotation forestry for economy and environmental benefits: country report (India). Indian Journal of Ecology, 38, 239-248

Glover, E. K., Hassan, B. A., and Glover, M. K. 2013. Analysis of socio-economic conditions influencing adoption of agroforestry practices. International Journal of agriculture and agroforestry, 3 (4), 178-184

Hussain, T., Khan, G. S., Khan, S.A., Masood, N., Ashfaq, M. and Sarwer, N. 2012.Farmers' agroforestry in Pakistan, Farmers' role -trends and attitudes. Current research journal of social science, 4(1), 29-35.

Irshad, M., Ashraf, M. and Sher, H. 2011. Identifying factors affecting agroforestry systems in Swat, Pakistan. African journal of agricultural research, 6 (11), 2586-2593

Kabwe, G. 2010.Uptake of agroforestry technologies among smallholder farmers in Zambia. Ph.D thesis submitted at Lincoln University. Christchurch, New Zealand.

Mukungei, P. K., Cheserek, G. J., Arusei, E. J., Chedotum, K., and Mining P. J. 2013. Socio-economic factors affecting farmers' in Turbo division, Usain Gishu County, Kenya. Journal of emerging trends in economics and management sciences, 41, 8-14

Leonida A. Bugayong Paper, 2003.Socioeconomic and Environmental Benefits of Agroforestry Practices in a Community-based Forest Management Site in the Philippines (research paper), The International Conference on Rural Livelihoods, Forests and Biodiversity, Bonn, Germany.

M. Chakraborty1, M.Z. Haider, M.M. Rahaman, 2015 Socio-Economic Impact of Cropland Agroforestry: Evidence from Jessore District of Bangladesh, International Journal of Research in Agriculture and Forestry Volume 2, Issue 1, January 2015, PP 11-20 ISSN 2394-5907 (Print) and ISSN 2394-5915.

Mutonyi, S. and Fungo, B. 2011.Patterns of agroforestry practices among small 
holder farmers in the Lake Victoria Crescent Zone, of Uganda. Research journal of applied sciences, 6(4), 251257

Mwase, W., Sefasi, A., Njoloma, J., Nyoka, B. I., Manduwa, D., and Nyaika, J. 2015.Factors affecting adoption of agroforestry and evergreen agriculture in Southern Africa. Environment and natural resource research, 5(2), 148-157

Oraon, P. R. Yadava, M. S. Siddiqui, M. H. 2005. Comparative performance of agroforestry system in Kumharia village of Ranchi district. Indian Journal of Agroforestry, 7 (2): 19-24.
Rana, B. S.; Saxena, A. K. and Parihar, A. K. S. 2007.Status and scope of agroforestry development in eastern part of Uttar Pradesh. Agroforestry: Systems and Practices, 20 (3): 191-211.

Salam, M.A., Babu, K. S. and Mohanakumaran, N.1999.Coconutbased mixed farming system to sustain productivity. Indian Coconut J. 20(10): $1-3$.

Singh, M. K. 2010. Socio-economics of climate change impact on agriculture land use changes in India. Phd thesis, Szentistván University Gödöllö.

\section{How to cite this article:}

Satyameshwari Chouhan, Sameer Daniel, Arun Alfred David and Anupriya Paul. 2017. Analysis Socioeconomic Status of Farmers Adopted Agroforestry of Basavanapura and Hejjige Village, Nanjangud, India. Int.J.Curr.Microbiol.App.Sci. 6(7): 1745-1753.

doi: https://doi.org/10.20546/ijcmas.2017.607.210 